\title{
Assessing the applicability of the CRM concept in a public autonomous institution
}

\author{
A.D. Lagunova , and A.A.Pastushkova* \\ MIREA-Russian technological University (RTU MIREA), 119454 Moscow, Prospekt Vernadskogo \\ 78, Russia
}

\begin{abstract}
In this article the issues of assessing the applicability of Customer Relationship Management in the processes and conditions of the functioning of autonomous state institutions are being examined. The authors consider the outlook of applying the concept of CRM, from the point of view of further implementation of CRM systems in the functional activities of the establishment.
\end{abstract}

\section{Introduction}

The CRM concept is an interaction model that is aimed at maximizing the life cycle by building long-term relationships with the client through the formation of loyalty with the help of personal proposals - an issue whose applicability assessment must be identified for use in state autonomous institutions.

\section{Materials and Methods}

Before considering the issues of customer relationship management of an organization, it is necessary to clarify its status and the restrictions it imposes on its activities. In this study, the authors propose to consider the activities of state autonomous institutions, which, according to Federal Law No. 174 of 03.11 .2006 , are defined as "a non-profit organization created by the Russian Federation, a constituent entity of the Russian Federation or a municipal formation to perform work, provide services in order to exercise the powers provided for by the legislation of the Russian Federation. Government bodies, the powers of local selfgovernment bodies in the spheres of science, education, health care, culture, mass media, social protection, employment of the population, physical culture and sports, as well as in other areas in cases established by federal laws (including activities to work with children and youth in these areas) ". [1]

To assess the applicability of the CRM concept to an organization of this type, it is necessary to determine the differences between a state autonomous institution and a commercial organization. The study of this issue in various sources, primarily legislative $[1,2,3]$, shows that at the current time there is a confusion of the legal status of an autonomous

\footnotetext{
*Corresponding author: pastushkovaanya@gmail.com
} 
state institution as a non-profit organization and commercial organizations engaged in entrepreneurial activity. The main differences between a state autonomous institution and a commercial organization are presented in Table 1.

Table 1. Differences between a state autonomous institution and a commercial organization.

\begin{tabular}{|c|c|c|}
\hline $\begin{array}{c}\text { Comparison } \\
\text { criterion }\end{array}$ & State autonomous institution & $\begin{array}{l}\text { Commercial organization } \\
\text { engaged in entrepreneurial } \\
\text { activity }\end{array}$ \\
\hline $\begin{array}{l}\text { Purpose of } \\
\text { creation }\end{array}$ & $\begin{array}{l}\text { To carry out certain functions of the } \\
\text { state in the social sphere, and Federal } \\
\text { Law No. } 174 \text { does not provide for the } \\
\text { extraction of profit by autonomous } \\
\text { institutions as the goal of their } \\
\text { activities. }\end{array}$ & Extraction of profit \\
\hline $\begin{array}{l}\text { Financing } \\
\text { guarantee }\end{array}$ & $\begin{array}{l}\text { According to paragraph } 1 \text { of Art. } 20 \text { of } \\
\text { the Federal Law of } 03.11 .2006 \mathrm{~N} 174- \\
\text { FZ "On Autonomous Institutions", the } \\
\text { founder is obliged to give a task and a } \\
\text { subsidy for its implementation, the cost } \\
\text { of providing paid services is carried out } \\
\text { at the expense of the institution's own } \\
\text { funds. }\end{array}$ & $\begin{array}{c}\text { None. The commercial entity } \\
\text { bears its own liability for its } \\
\text { obligations. }\end{array}$ \\
\hline $\begin{array}{l}\text { Distribution of } \\
\text { profits between } \\
\text { participants }\end{array}$ & $\begin{array}{l}\text { No distribution of profits between } \\
\text { participants }\end{array}$ & $\begin{array}{l}\text { Profits are distributed between } \\
\text { the participants }\end{array}$ \\
\hline $\begin{array}{l}\text { Legal capacity } \\
\text { of the above } \\
\text { types of } \\
\text { subjects of civil } \\
\text { transactions } \\
\end{array}$ & $\begin{array}{l}\text { Allows the named type of institution as } \\
\text { an economic entity to conclude civil } \\
\text { law contracts with any counterparties. }\end{array}$ & $\begin{array}{l}\text { Allows the named type of } \\
\text { institution as an economic entity } \\
\text { to conclude civil law contracts } \\
\text { with any counterparties. }\end{array}$ \\
\hline $\begin{array}{c}\text { Means of } \\
\text { earning money }\end{array}$ & $\begin{array}{l}\text { The broadest freedom in raising funds } \\
\text { within the established framework, in } \\
\text { comparison with a budgetary institution }\end{array}$ & Complete freedom of action \\
\hline Profits & $\begin{array}{l}\text { They come into its own disposal and } \\
\text { are used by it to achieve the goals for } \\
\text { which it was created, unless otherwise } \\
\text { provided by law. Moreover, the owner } \\
\text { of the property of the autonomous } \\
\text { institution does not have the right to } \\
\text { receive income from the autonomous } \\
\text { institution's activities and the use of the } \\
\text { property assigned to the autonomous } \\
\text { institution (clauses } 8,9 \text {, article } 2 \text { of } \\
\text { Law N 174-FZ), which also determines } \\
\text { its special legal regime. }\end{array}$ & $\begin{array}{l}\text { Become available for its own } \\
\text { disposal }\end{array}$ \\
\hline State subsidies & $\begin{array}{l}\text { Allocated to carry out government or } \\
\text { administrative assignments from the } \\
\text { founder }\end{array}$ & $\begin{array}{c}\text { Not expected (subsidies are } \\
\text { possible within the framework } \\
\text { of state business support } \\
\text { programs under a number of } \\
\text { conditions) }\end{array}$ \\
\hline
\end{tabular}

It should be emphasized that subsidiary support of autonomous institutions is intended solely to fulfill the task of the founder. The autonomous institution must find the resources necessary for the provision of paid services on its own at its own expense. Thus, in modern 
conditions, the main goal of the functioning of an autonomous institution is to make a profit. [4]

At the same time, the basis for the management of autonomous institutions is a task formed by the founder, which cannot be canceled, and which is aimed at the implementation of work, the provision of services in order to exercise the powers of state authorities provided for by the legislation of the Russian Federation in such areas as: science, education, health care, culture , mass media, social protection, employment of the population, physical culture and sports. [1,5]

In view of the fact that the main activity of the institution is the provision of services, and the largest group of subjects are consumers, we will consider the process of interaction with this target audience.

As noted above, the involvement of the institution in the state and partial funding at its expense should be noted. Most of them are aimed at working with individuals on a budgetary or preferential basis. At the same time, attention should be paid to the work on the provision of services on a paid basis, which is advisable to optimize in order to increase the profit of the institution from this type of service. Considering this activity as interaction with the institution's clients, we will assess the applicability of the CRM concept from the standpoint of the transition to a customer-oriented approach.

At the same time, it is extremely important to separate CRM as a business concept (strategy) and CRM as a project for the implementation of information systems and technologies of the same class. The authors are of the opinion that these concepts are related as "general" and "particular", and it is not advisable to consider the second outside the contour of the first, since such an approach will not allow realizing the key effects of this strategy. This position can be confirmed by a number of authoritative opinions, for example, E. Payne, as one of the recognized researchers in the field of CRM efficiency [6], as well as the collected statistics on the reasons for failures in the implementation of CRM systems (Fig. 1). As you can see, more than a third of all failures (36\%) are associated with failures in the development of strategic aspects of the project (setting goals and developing strategies).

\section{Causes of failures in CRM systems introduction}

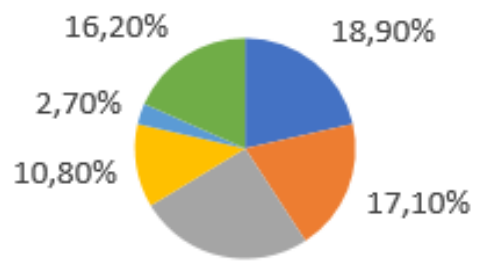

$22,50 \%$
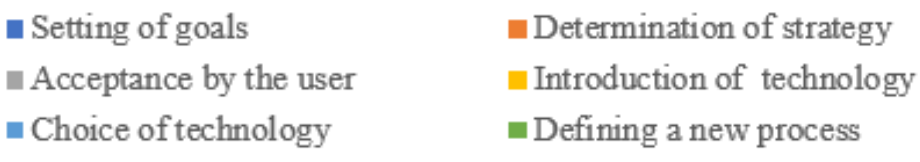

Fig. 1. Causes of failures in CRN systems introduction [7]

The concept of CRM, aka the system of internal standards and business processes for customer service, appeared in the mid-1990s. An engagement model that assumes that the customer is at the center of the entire business philosophy and that the focus is on measures 
to support effective marketing, sales and customer service. Supporting these business goals includes collecting, storing and analyzing information about customers, suppliers, partners, as well as about the internal processes of the company.

A customer-centric approach is a strategy by which a company collects information about its customers at all stages of its life cycle (attraction, retention, loyalty), extracts knowledge from it and uses this knowledge in the interests of its business by building mutually beneficial relationships with them, based on using advanced management and information technologies.

The purpose of applying the strategy is to maximize the full value of the client throughout the entire life cycle, and as a result - to increase the company's competitiveness, since wellbuilt relationships based on a personalized approach to each client and maintaining a balance of values (created by the organization for the client and the client for the organization), allow you to retain customers and help attract new ones.

In the CRM concept, there is a focus not on the product, but on the client with personalization of offers. Often, to increase profitability, customer companies are segmented into different categories (for example, using ABC-, RFM- and other types of analysis) and develop several different methods of serving customers depending on their belonging to a particular group. At the same time, it is extremely important to rationally provide services by tracking the value of relationships for the client and for the organization, and as a result - to maximize the full profit from the client throughout the entire life cycle.

Let us assess the possibility of applying the CRM concept in a state autonomous institution according to the key features of customer relationship management in Table 2, highlighted on the basis of an assessment of implementation in a state autonomous institution.

Table 2. Assessment of the application of the CRM concept in a state autonomous institution

\begin{tabular}{|c|c|}
\hline $\begin{array}{l}\text { Key features of the } \\
\text { CRM concept }\end{array}$ & Assessment of implementation in a state autonomous institution \\
\hline $\begin{array}{l}\text { Focus on customer } \\
\text { retention and increasing } \\
\text { their total bottom line as } \\
\text { part of a targeted } \\
\text { customer retention } \\
\text { strategy }\end{array}$ & $\begin{array}{l}\text { Let's consider the state autonomous institution clients from the point of view of } \\
\text { receiving services: } \\
\text { - budgetary basis. the state autonomous institution is interested both in re-applying } \\
\text { on a preferential basis at the expense of the state budget and for a commercial } \\
\text { service (implementation of a cross-sale approach due to the complex } \\
\text { implementation of techniques, but pay special attention to the sales matrix, the } \\
\text { method of communicating with customers, as well as employee motivation). } \\
\text { - commercial basis. Institutions are interested not only in attracting and retaining } \\
\text { customers, but also in increasing the amount of sale (implementation of the up-sale } \\
\text { principle). }\end{array}$ \\
\hline $\begin{array}{l}\text { Arranging relationships } \\
\text { with a range of } \\
\text { stakeholders that } \\
\text { contribute to the market } \\
\text { efficiency of the } \\
\text { company }\end{array}$ & $\begin{array}{l}\text { Let's highlight the following stakeholders and their states according to OMG } \\
\text { Essence - Kernel and Language for Software Engineering Methods [8]. This } \\
\text { standard provides a description of the life cycle of each stakeholder, as well as their } \\
\text { interactions. } \\
\text { - founder (involved) - as a rule, this is a representative of a constituent entity of the } \\
\text { Russian Federation or a higher-level institution. Interaction is based on the receipt } \\
\text { and control of the fulfillment of a state or administrative assignment, assessment of } \\
\text { the effectiveness of the institution's work; } \\
\text { - regulatory authorities (represented). It is extremely difficult to influence the } \\
\text { loyalty of a relationship. All interaction takes place with various representatives of } \\
\text { regulatory bodies and is formed on the basis of unilateral relations by providing } \\
\text { accounting documents. } \\
\text { - the customer of the service (involved, in agreement. Loyalty is formed due to } \\
\text { satisfaction with the service provided; } \\
\text { - state autonomous institution employees (involved, in agreement) Employee } \\
\text { loyalty is formed by external motivation (bonuses, benefits, career growth) and } \\
\text { internal (team atmosphere, relationships at work, personal growth). }\end{array}$ \\
\hline $\begin{array}{l}\text { Emphasis on cross- } \\
\text { functional marketing } \\
\text { approach }\end{array}$ & $\begin{array}{l}\text { Currently, lower-level institutions (district/municipal) are focused on a functional } \\
\text { approach, but there are opportunities for implementing a cross-functional (mixed) } \\
\text { approach, as in higher-level organizations (city/federal district or state level). }\end{array}$ \\
\hline
\end{tabular}




\section{Results and Discussion}

Thus, the data presented in the table allows us to conclude about the applicability of the CRM concept in an autonomous institution. Regardless of the institution's involvement in the state or its independence, it is advisable to apply the CRM concept when working with clients. This will increase the loyalty of both buyers and other contact audiences, which will allow you to count on re-applying for the service.

Managing customer relationships in an autonomous institution means: implementing the procedure for attracting new customers, transforming neutral buyers into loyal customers, and making regular

customers your business partners (agents). Such a scheme is valid in any market, and only competent customer relationship management allows to work according to it. And although the main regulations usually affect the front office of the organization, namely three areas (sales, marketing and service), the degree of customer satisfaction and loyalty also largely depends on the activities of the back office: the quality of the service provided, the timing of its implementation, and the organization of mutual settlements.

Customer service schedules are a chain of small elements that are often overlooked. But it is these elements that play a key role, here are examples of some of them:

- $\quad$ script for answering a phone call;

- $\quad$ speed of reaction to the client's request;

- $\quad$ structure of the commercial proposal;

- loyalty program scheme;

- an offer to purchase related products, etc.

Like any project, a CRM project should begin with a survey of the current situation, it is necessary to conduct a CRM audit - an audit of the current level of customer relations. The overall strategic structure of CRM can be defined by five main processes, such as: the strategy development process; value creation process; multichannel integration process; information management process; the process of evaluating the effectiveness [4]. The procedure for applying this scheme in a state autonomous institution remains the same as for commercial enterprises, with some adjustment in terms of customer segmentation: that part of customers who are served within the framework of an assignment from the founder for the provision of services in order to exercise the powers of state bodies provided for by the legislation of the Russian Federation authorities do not have to go through the process of assessing the value received by the institution (stage of the value creation process). The process of evaluating effectiveness in terms of results for shareholders also requires adjustments.

It should be noted that the issues of adapting the strategic structure of CRM in a government agency are beyond the scope of this article.

\section{Conclusions}

Thus, the CRM concept is applicable to government agencies and includes an orientation towards personalized offerings.

As mentioned earlier, it is advisable to classify clients by different types of analyses and provide services in accordance with this. When implementing CRM systems, it is necessary to rely on the experience of successful projects. It is important to understand that the system is only part of the tool for attracting and retaining customers, and the main focus is on the company's strategy. 


\section{Acknowledgements}

The article was prepared within the framework of writing a master's thesis on information systems and technologies together with the diploma supervisor.

\section{References}

1. Federal Law "On Autonomous Institutions" dated 03.11.2006 N 174-FZ

2. Federal Law "On Amendments to Certain Legislative Acts of the Russian Federation in Connection with the Improvement of the Legal Status of State (Municipal) Institutions" dated 08.05.2010 N 83-FZ

3. Federal Law "On Non-Commercial Organizations" of 12.01.1996 N 7-FZ

4. E. Polotovskaya, Ezh-Lawyer, 47 (2011)

5. BC RF Article 69.2. State (municipal) task

6. Adrian Payne. Handbook of CRM: Achieving Excellence in Customer Management

7. CRM Landmark, http://www.crmlandmark.com/

8. Object Management Group / Essence - Kernel and Language for Software Engineering Methods, 10 (2018) 